\title{
Trypanosoma cruzi: susceptibility to chemotherapy with benznidazole of clones isolated from the highly resistant Colombian strain
}

\author{
Trypanosoma cruzi: suscetibilidade à quimioterapia com o benzonidazol de \\ clones isolados da cepa Colombiana, altamente resistente
}

\author{
Edson L.P. Camandaroba ${ }^{1}$, Eliana A.G. Reis ${ }^{2}$, Marilda S. Gonçalves ${ }^{2}$, \\ Mitermayer G. Reis ${ }^{2}$ and Sonia G. Andrade ${ }^{1}$
}

\begin{abstract}
The present investigation was performed to evaluate the susceptibility of seven clones isolated from the highly resistant Colombian strains, prototype of Biodeme Type III. Seven clones previously obtained, showed a phenotypic homogeneity and high similarity with the parental strain. Eight groups of 30 mice were inoculated with one of seven clones or the parental strain; 20 were treated with benznidazole $(100 \mathrm{mg} / \mathrm{kg} /$ day $)$ and 10 were untreated controls. Cure evaluations were done by parasitological and serological tests and PCR. Cure rates varied from $0 \%$ (null) to $16.7 \%$. Correlation between positivity of parasitological and serological tests with positive PCR reached $37 \%$. The results demonstrated the high resistance of the clones, suggesting the predominance of a highly resistant principal clone in this strain. The findings apparently indicate that the possibility of cure is minimal for patients infected with this biodeme; a fact that could affect the control of Chagas' disease through treatment of chronically infected people.
\end{abstract}

Key-words: Chagas' disease. Trypanosoma cruzi. Clones. Chemotherapy. Resistance. Benznidazole.

Resumo A presente investigação visa avaliar a suscetibilidade ao benzonidazol de sete clones isolados da cepa Colombiana do Trypanosoma cruzi, protótipo do biodema III , altamente resistente aos quimioterápicos. Os clones préviamente obtidos apresentavam homogeneidade fenotípica e alta similaridade com a cepa parental. Oito grupos de 30 camundongos foram inoculados com cada um dos sete clones e a cepa parental;20 foram tratados com benzonidazol $100 \mathrm{mg} / \mathrm{kg} /$ dia e 10 foram controles não tratados. A avaliação da cura foi feita por testes parasitológicos, sorológicos e o PCR. Os índices de cura variaram de 0\%(nulo) a 16,7\%. Correlação entre a positividade dos testes parasitológicos e sorológicos com a da PCR alcançou 37\%. Os resultados demonstraram a alta resistência dos clones, sugerindo a predominância de um clone principal, muito resistente à quimioterapia nesta cepa. Isto indica que as possibilidades de cura de pacientes infectados com este biodema são mínimas, o que poderá interferir no controle da doença através do tratamento de individuos cronicamente infectados.

Palavras-chaves: Doença de Chagas. Trypanosoma cruzi. Clones. Quimioterapia. Resistência. Benzonidazol.

Among endemic areas of Chagas' disease in Brazil, in which transmission by the vector insect is only partially controlled, 5 million people are estimated to be chronically infected ${ }^{30}$. Treatment of infected people in endemic areas has been recommended by the National Health Foundation of Brazil for acute or recent chronic cases ${ }^{19}$ as well as for congenital and accidental infections and for children with positive serology. It is also indicated for patients with acquired immmunodeficiency syndrome (AIDS) and for those undergoing organ transplantation or receiving immunosuppressive drugs, which present a risk for reactivation of latent infection with $T$. cruzi' ${ }^{19}$. However, success of treatment with currently used drugs (Nifurtimox or Benznidazole) is limited by the prevalence of $T$. cruzi strains resistant to these chemotherapeutics ${ }^{3521}$. It has been shown that resistance is correlated with biological characteristics of the parasite. The Type III biodeme, of which the prototype is the Colombian strain, is highly resistant ${ }^{5}$. Strains isolated from mice previously treated with benznidazole showed increased resistance

1. Laboratorio de Doença de Chagas Experimental do Centro de Pesquisas Gonçalo Moniz da Fundação Oswaldo Cruz, Salvador, BA. 2. Laboratório de Patologia e Biologia Molecular do Centro de Pesquisas Gonçalo Moniz da Fundação Oswaldo Cruz, Salvador, BA

Financial support: this work was sponsored by the "Programa de Apoio à Pesquisa Estratégica em Saúde" (Papes 2) - FIOCRUZ -Rio de Janeiro-Brazil Address to: Dra. Sonia G. Andrade. Laboratório do Centro de Pesquisas Gonçalo Moniz/FIOCRUZ. R. Waldemar Falcão 121, Brotas, 40295-001 Salvador, BA, Brazil.

Fax: 5571 356-4292

Recebido para publicação em 10/1/2002 
to treatment with the same $\mathrm{drug}^{4}$, suggesting the selection of resistant clones to explain the persistence of infection in treated mice. Marretto and Andrade ${ }^{22}$ investigated this possibility by studying the isoenzymic profiles of the Colombian strain isolated from treated mice, but no phenotype differences were detected by comparison of the isoenzymic profiles. Murta \& Romanha ${ }^{24}$ performed the in vivo selection of nitroderivates-resistant clones from the $Y$ strain, and concluded that the resistance of the strain could be related to the sensitive/resistant clone ratio in the population.

Considering that $T$. cruzi strains are complex clonal populations ${ }^{26}$, it is important to evaluate the susceptibility to treatment of a representative number of individual clones. A previous study ${ }^{14}$ demonstrated the identity of seven clones obtained from the Colombian strain, based upon biological behavior or isoenzymic profiles. The possibility of the predominance of a principal clone, as representative of strains circulating in a single endemic area, has been recently suggested ${ }^{2}{ }^{16}$. This could be decisive for the success of treatment of chronic patients, considering the possibility of predominance of a highly resistant principal clone in one geographical area. Although the Colombian strain has been characterized as resistant, the presence of susceptible clones cannot be ruled out. In a population of parasites with mixed susceptibilities, a partial response to treatment could be expected in infected individuals, with a decrease in the parasite load. In the present study, in which the seven clones of the Colombian strain were tested for susceptibility to benznidazole, results obtained in mice were evaluated by various parasitological tests, as well as by polymerase chain reaction (PCR). This test has been recently included for the diagnosis of chronic infection in humans ${ }^{101112}$ and as a cure test in treated patients ${ }^{13}$. An evaluation of the sensitivity of this test has been performed in the blood containing known aliquots of trypomastigotes ${ }^{17}$. However, the sensitivity of PCR for post-treatment detection of sub-patent parasitemia in mice has not been previously evaluated, in comparison with the standard tests. The present study examined the susceptibility to chemotherapy of individual clones from a resistant strain and the value of PCR as a cure test.

\section{MATERIAL AND METHODS}

Experimental animals. For the present study, 240 Swiss outbred mice were used. Maintenance and care of experimental animals complied with the Centro de Pesquisas Gonçalo Moniz/FIOCRUZ guidelines for humane use of laboratory animals.

Trypanosoma cruzi strain: the Colombian strain 20 biologically characterized as Biodeme Type $\mathrm{III}^{4}$ Zymodeme $1^{423}$ and recently included into the group T. cruzi $l^{8}$ was used for all the experiments.

Clones from the Colombian strain: clones were obtained by isolation of a single form according to Dvorak $^{18}$ from peripheral blood of Swiss outbred mice, infected with the parental strain as previously described ${ }^{14}$.

Identification of the isolated clones: seven clones were isolated and denominated as follows: $\mathrm{Cl}-\mathrm{Col}-\mathrm{C} 1$, C2, C3, C4, C5, C6 and C7.

Chemotherapy: eight experimental groups of 30 mice, weighing from 10 to $12 \mathrm{~g}$, were infected with $5 \times 10^{4}$ to $1 \mathrm{x}$ $10^{5}$ trypomastigotes from the parental strain or one of the seven clones (Table 2). Twenty infected mice from each group were submitted to chemotherapy and 10 remained as untreated controls. Benznidazole (N-benzyl2-nitro-1-imidazole-acetamide) $100 \mathrm{mg} / \mathrm{kg}$ of body weight / day was administered daily by gavage, from 20 days post infection up to 90 days. Following treatment, parasitemia was evaluated on alternate days, and the results were evaluated as the mean obtained in five mice from each experimental group. Parasitemia of infected non-treated controls was similarly evaluated.

Evaluation of treatment: a total of 83 mice that survived from the treatment groups were submitted to parasitological tests and serological examination to detect cure rates. Parasitemia was examined for 30 days following the end of treatment, to detect positivity by direct examination. The mice that maintained a negative parasitemia were submitted to the parasitological cure tests: subinoculation and haemoculture; serology and PCR were also used as cure tests. A total of 21 untreated mice that survived from the eight groups (Table 1) were similarly evaluated during the post-treatment period.

Subinoculation: citrated blood from each mouse $(0.5 \mathrm{ml})$ was intraperitoneally inoculated into 5 suckling mice. Blood examination was performed until 20 days post inoculation to detect the presence of trypomastigotes.

Haemoculture: this was performed in Warren axenic medium ${ }^{28}$ with $0.5 \mathrm{ml}$ of blood directly collected from the heart, and the cultures were examined after 45 days.

Serological test: indirect immunofluorescence test (IFT) was performed using as antigen, culture forms of T. cruzi in Warren medium, washed three times by centrifugation with PBS $\mathrm{pH} 7.2$, formalin fixed and mounted on glass slides. Sera were tested in decreasing concentrations, from 1:10 to $1: 640$. Fluoresceinated antimouse rabbit lgG secondary antibody was diluted at 1:80.

Polymerase chain reaction (PCR): a total of 54 samples of blood were obtained from treated mice, 7 infected with the parental strain and 47 with the clones. As controls, 5 samples from untreated mice infected with the parental strain were tested by PCR.

The blood samples $(500 \mathrm{ml})$ were strored at $4^{\circ} \mathrm{C}$ in $1: 1$ guanidine $6 \mathrm{M} /$ EDTA $0.2 \mathrm{M} \mathrm{pH} 8.0$ solution for a maximum of 30 days until processing. 
Isolation of the kinetoplast DNA (kDNA) was performed according to Wincker et $\mathrm{al}^{29}$. For amplification of a 330 bp fragment primers P35: 5'AAA TAA TGTACG GG (T/G)GAGATG CATGA 3' and P36: 5'GGG TTC GAT TGG GGT TGG TGT3'd NTPs and 2.5U of Taq Polymerase (Perkin Elmer Cetus Corporation ) were added to the isolated $\mathrm{k}$ DNA. After an initial $5 \mathrm{~min}$ denaturation step at $94^{\circ} \mathrm{C}, 35$ cycles of amplification were performed in a Thermal Cycler (Perkin-Elmer-Cetus gene Amp PCR System 9600) with a step program consisting of $45 \mathrm{sec}$ denaturation at $94^{\circ} \mathrm{C}, 45 \mathrm{sec}$ annealing at $55^{\circ} \mathrm{C}$ and 1 min extension at $72^{\circ} \mathrm{C}$ and 1 min extension at $72^{\circ} \mathrm{C}$ The product of PCR electrophoresed in $2 \%$ agarose gel in TAE buffer (0.04M Tris-acetate, $0.001 \mathrm{M}$ EDTA) and stained with ethidium bromidium. As DNA ladder, 100 base pair marker (Amersham Pharmacia Biotech) was used. Each PCR batch included a negative control (blood sample from uninfected mouse) and a positive control (culture forms of T. cruzi). In order to confirm the specificity of the amplified fragment it was analyzed by dot blot hybridization using allele specific probe P67 (5'TGGTTTTGGGG(C/G $0(G / C)(T / G) T C A A(A / C)$ TTT 3'). Labeling the 5 ' end of the oligonucleotide probe was performed using the radioactive nucleotide $\left[\mathrm{g}^{-32} \mathrm{P}\right] \mathrm{ATP}$ and the T4 polynucleotide kinase enzyme (Kit Ready-To-Go T4 Polynucleotide kinase Pharmacia Biotech) and autoradiography was performed.

\section{RESULTS}

Parasitemia. As shown in Figures 1a, 1b, 1c and 1d, parasitemic levels of treated animals markedly decreased in the different experimental groups during treatment Negative parasitemia (by direct blood examination) was

Colombian strain

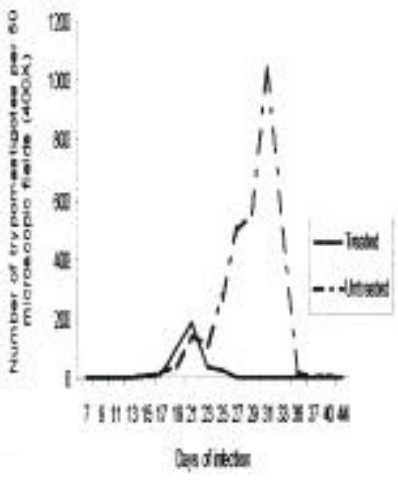

A

Clone CL-Col-C2

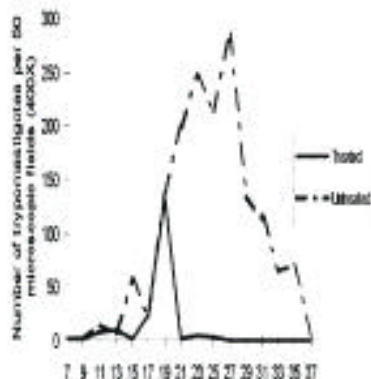

C

Figure 1 - Parasitemia in mice infected with T. cruzi (Colombian strain and its clones): untreated control (dashed line) and treated with benznidazole (solid line): a) parental strain, b) clone Cl-Col-C1, c) clone Cl-Col-C2, d) clone Cl-Col-C3. A marked decrease of parasitemic levels of treated animals is seen from the beginning of treatment in the different experimental groups. observed from day 2 - 8 of treatment with slight differences between the clones. In the post treatment phase (120 days on), positive direct parasitemia was detected in 19/ 83 mice $(22 \%)$.

\section{Clone $\mathrm{Cl} \cdot \mathrm{Col}-\mathrm{Cl}$}

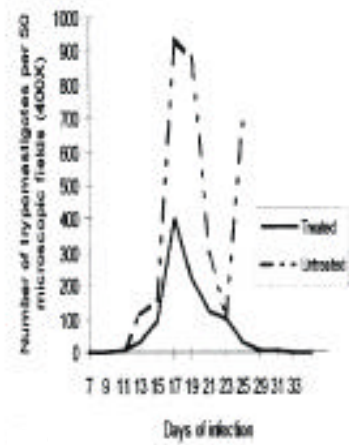

B

Clone $\mathrm{CL}-\mathrm{Col}-\mathrm{C} 3$

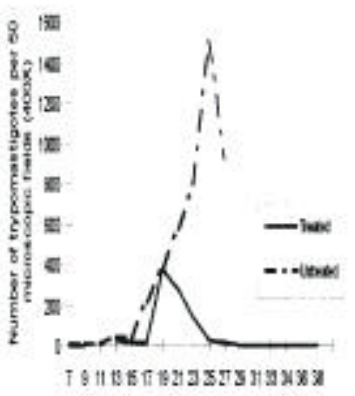

ans fitcen 
Untreated controls showed negative parasitemia (by direct blood examination, from the day 37 on). In the post treatment phase positive parasitemia to direct blood examination was detected in 11/21 mice (52.3\%).

Mortality. Cumulative mortality and the number of survivors in the different experimental groups are expressed in Table 1. Peak mortality occurred at day 30 of infection, and decreased with treatment, except for the mice infected with clone $\mathrm{C} 1$, with high mortality. The untreated mice showed a significantly higher mortality when compared with the treated animals, except for
Clone C2, with low mortality. From 160 treated mice 83 animals survived (mortality rate $48 \%$ ) and from 80 untreated mice, 21 survived (mortality rate $73 \%$ ).

Parasitological cure tests. Positivity of at least one test (direct blood examination, subinoculation into newborn mice or haemoculture) was defined as cure failure; positive parasitological tests were present in $50 \%$ to $100 \%$ of the mice examined 30 days after the end of treatment, for the parental strain and the 7 clones (Table 2). The untreated controls were $100 \%$ positive by parasitological tests.

\begin{tabular}{|c|c|c|c|c|c|c|}
\hline \multicolumn{4}{|c|}{ Experimental groups } & \multicolumn{3}{|c|}{ Cumulative mortality } \\
\hline \multirow{3}{*}{ Days infection } & \multicolumn{3}{|c|}{ treated $^{*}$} & \multirow{3}{*}{ survivors number } & \multicolumn{2}{|c|}{ untreated $^{\star *}$} \\
\hline & 30 & 60 & $90-120$ & & $20-90$ & survivors number \\
\hline & $\%$ & $\%$ & $\%$ & & $\%$ & \\
\hline Parental strain & 40.0 & 0.0 & 0.0 & 12 & 20.0 & 8 \\
\hline $\mathrm{Cl}-\mathrm{Col}-\mathrm{C} 1$ & 60.0 & 65.0 & 80.0 & 4 & 60.0 & 4 \\
\hline $\mathrm{Cl}-\mathrm{Col}-\mathrm{C} 2$ & 10.0 & 0.0 & 0.0 & 18 & 0.0 & 10 \\
\hline $\mathrm{Cl}-\mathrm{Col}-\mathrm{C} 3$ & 40.0 & 0.0 & 0.0 & 12 & 100.0 & 0 \\
\hline CL-Col-C4 & 75.0 & 0.0 & 0.0 & 5 & 90.0 & 1 \\
\hline Cl-Col-C5 & 50.0 & 0.0 & 0.0 & 10 & 80.0 & 2 \\
\hline CL-Col-C6 & 60.0 & 0.0 & 0.0 & 8 & 100.0 & 0 \\
\hline CL-Col-C7 & 30.0 & 0.0 & 0.0 & 14 & 80.0 & 2 \\
\hline Total & & & & 83 & & 21 \\
\hline
\end{tabular}

* Initial number: 20 mice; ${ }^{*}$ Initial number: 10 mice

Table 2- Cure rates in mice infected with Trypanosoma cruzi (Colombian strain and 7 clones), treated with benznidazole, based on parasitological and serological tests.

\begin{tabular}{|c|c|c|c|c|c|c|}
\hline \multirow[b]{2}{*}{ Identification } & \multirow[b]{2}{*}{ Inocula } & \multirow[b]{2}{*}{ Mice (\#) } & \multirow[b]{2}{*}{ Positive cases(\#) } & \multicolumn{2}{|c|}{ Positive } & \multirow{2}{*}{$\begin{array}{c}\text { Cure } \\
\text { rates }{ }^{\text {b } \%}\end{array}$} \\
\hline & & & & parasitol tests $\%$ & serology $\mathrm{a} \%$ & \\
\hline Col Strain & $5 \times 10^{4}$ & 12 & 12 & 84.0 & 88.8 & 0.0 \\
\hline $\mathrm{Cl}-\mathrm{Col}-\mathrm{C} 1$ & $5 \times 10^{4}$ & 4 & 4 & 100.0 & 100.0 & 0.0 \\
\hline $\mathrm{Cl}-\mathrm{Col}-\mathrm{C} 2$ & $1 \times 10^{5}$ & 18 & 18 & 100.0 & 100.0 & 0.0 \\
\hline $\mathrm{Cl}-\mathrm{Col}-\mathrm{C} 3$ & $5 \times 10^{4}$ & 12 & 10 & 66.6 & 69.0 & 16.7 \\
\hline $\mathrm{Cl}-\mathrm{Col}-\mathrm{C} 4$ & $5 \times 10^{4}$ & 5 & 5 & 100.0 & 100.0 & 0.0 \\
\hline $\mathrm{Cl}-\mathrm{Col}-\mathrm{C} 5$ & $1 \times 10^{5}$ & 10 & 9 & 50.0 & 100.0 & 0.0 \\
\hline $\mathrm{Cl}-\mathrm{Col}-\mathrm{C} 6$ & $1 \times 10^{5}$ & 8 & 8 & 62.5 & 100.0 & 0.0 \\
\hline Cl-Col-C7 & $5 \times 10^{4}$ & 14 & 14 & 69.0 & 100.0 & 0.0 \\
\hline Total & & 83 & 80 & & & \\
\hline
\end{tabular}

Serologic reaction. the indirect immunofluorescence test (IFT) revealed positive results for $94 \%$ of treated animals 30 days after the end of treatment (Table 2 ); the minimal titer considered as positive was 1:20. Titers varied from 1:20 to 1:640 for the parental strain and the seven clones (Tables 3 and 4). Untreated controls showed positive IFT with titers varying from 1:80 to $1: 640$.

Polymerase chain reaction. The PCR amplification and hybridization revealed the presence of $330 \mathrm{bp}$ fragments from the kDNA amplified minicircles as shown in Figures 2, 3 and $4 ; 29.2 \%$ of blood samples obtained from treated mice were positive by PCR versus $40 \%$ of the controls (infected, not treated).

Cure rates. Cure rates were established by the combination of parasitological test results and IFT titers, from the titter of 1:20 (Table 2). Following this criterion the parental strain and all the clones with the exception of Clone C3 presented 0\% cure. Clone C3 showed 16.7\% cure. Comparison between the results of parasitological cure tests, serological tests and PCR are expressed in 
Table 3- Comparison of results of parasitological tests, serology and PCR in mice infected with the Colombian parental strain and submitted to benznidazole therapy.

\begin{tabular}{|c|c|c|c|c|c|}
\hline \multirow[b]{2}{*}{ Mice (\#) } & \multicolumn{3}{|c|}{ Parasitological tests } & \multirow{2}{*}{$\begin{array}{l}\text { Serological } \\
\text { IIF titers }{ }^{\mathrm{b}}\end{array}$} & \multirow{2}{*}{$\begin{array}{r}\text { Molecular } \\
\text { test/PCR }\end{array}$} \\
\hline & Parasitemia $^{a}$ & subinoculation & hemoculture & & \\
\hline 03 & neg & neg & neg & $1: 20$ & * \\
\hline 04 & neg & neg & neg & $1: 640$ & neg \\
\hline 05 & neg & pos & neg & $1: 320$ & * \\
\hline 06 & neg & pos & pos & $1: 640$ & neg \\
\hline 07 & neg & pos & neg & $1: 40$ & pos \\
\hline 08 & neg & pos & neg & neg & pos \\
\hline 09 & neg & pos & neg & $1: 160$ & neg \\
\hline 10 & pos & * & * & * & * \\
\hline 11 & neg & pos & neg & $1: 320$ & pos \\
\hline 12 & neg & pos & neg & $1: 320$ & * \\
\hline 14 & neg & pos & pos & $1: 640$ & pos \\
\hline 15 & pos & * & * & * & * \\
\hline
\end{tabular}

Table 4- Comparison of results of parasitological tests, serology and PCR in mice infected with the clone $\mathrm{Cl}-\mathrm{Col}-\mathrm{C} 7$, treated with benznidazole.

\begin{tabular}{|c|c|c|c|c|c|}
\hline \multirow[b]{2}{*}{ Mice (\#) } & \multicolumn{3}{|c|}{ Parasitological tests } & \multirow{2}{*}{$\begin{array}{l}\text { Serological } \\
\text { IIF titers }\end{array}$} & \multirow{2}{*}{$\begin{array}{r}\text { Molecular } \\
\text { test/PCR }\end{array}$} \\
\hline & Parasitemia $^{a}$ & subinoculation & hemoculture & & \\
\hline 1 & neg & pos & pos & $1: 320$ & neg \\
\hline 2 & neg & pos & pos & $1: 320$ & neg \\
\hline 3 & neg & * & neg & $1: 640$ & neg \\
\hline 4 & pos & pos & * & * & * \\
\hline 5 & neg & * & pos & $1: 640$ & pos \\
\hline 6 & neg & * & pos & $1: 640$ & pos \\
\hline 7 & neg & pos & pos & $1: 640$ & neg \\
\hline 8 & neg & pos & pos & $1: 640$ & pos \\
\hline 9 & neg & pos & neg & $1: 640$ & neg \\
\hline 10 & neg & pos & pos & $1: 640$ & neg \\
\hline 11 & neg & pos & pos & $1: 640$ & pos \\
\hline 12 & neg & neg & neg & $1: 640$ & pos \\
\hline 13 & neg & pos & pos & $1: 640$ & pos \\
\hline 14 & neg & neg & neg & $1: 160$ & neg \\
\hline
\end{tabular}

* Test not done

a: Cases with positive direct parasitemia were not submitted to the other tests

b. Indirect immunofluorescence test

Tables 3 and 4 for mice infected with the parental strain or clone $\mathrm{C} 7$ as examples of the results from different tests, obtained in groups infected with several clones.

Correlation between parasitological tests and PCR. In mice with positive parasitological tests (from which samples were tested by PCR) $37 \%$ were positive by PCR and $57 \%$ were negative. In mice with negative parasitological tests, samples tested by PCR were negative in $3.7 \%$ and positive in $1.8 \%$ (Tables 3 and 4).

\section{DISCUSSION}

Analysis of the biological behaviour of clones isolated from the Colombian strain, prototype of Type III, Zymodeme 1 of $T$. cruzi, showed clonal homogeneity ${ }^{14}$. This was considered suggestive of the predominance of a principal clone ${ }^{216}$, according to the concept of Tibayrenc et $a^{R^{6}}$ and Tibayrenc and Breniere ${ }^{27}$. Studies of Revollo et $a^{25}$ have shown a clear relationship between the genetic profiles of clonal populations of T. cruzi and its biological characteristics, including the response to chemotherapy.

In the present investigation, the homogeneity of biological characteristics and isoenzyme patterns of seven clones as previously described ${ }^{14}$, corresponded to similar resistance to chemotherapy. Treatment of 


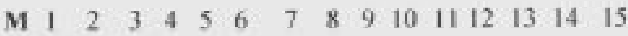

A

$100 \mathrm{bp}$

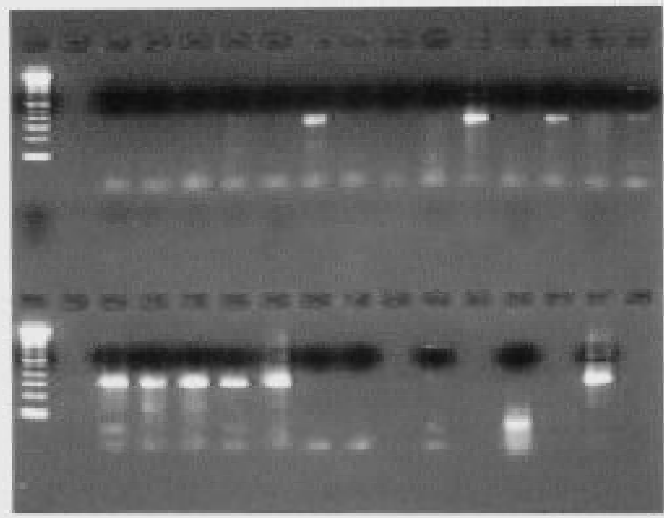

330 bp

B

M $\quad 16 \quad 17 \quad 1819202122 \quad 23 \quad 24 \quad 25$

Figure 2 - k DNA Amplification: a: clone Cl-Col-C2: samples 1 to 11 and clone Cl-Col-C7: samples 12 to 14. b: Clone Cl-Col-C7: samples 16 to 22 and Positive control (culture forms of T. cruzi): 25 . Negative control (blood of normal mouse): 24. Negative control (ultra pure water without DNA samples): 23. M: marker ladder: $100 \mathrm{bp}$.

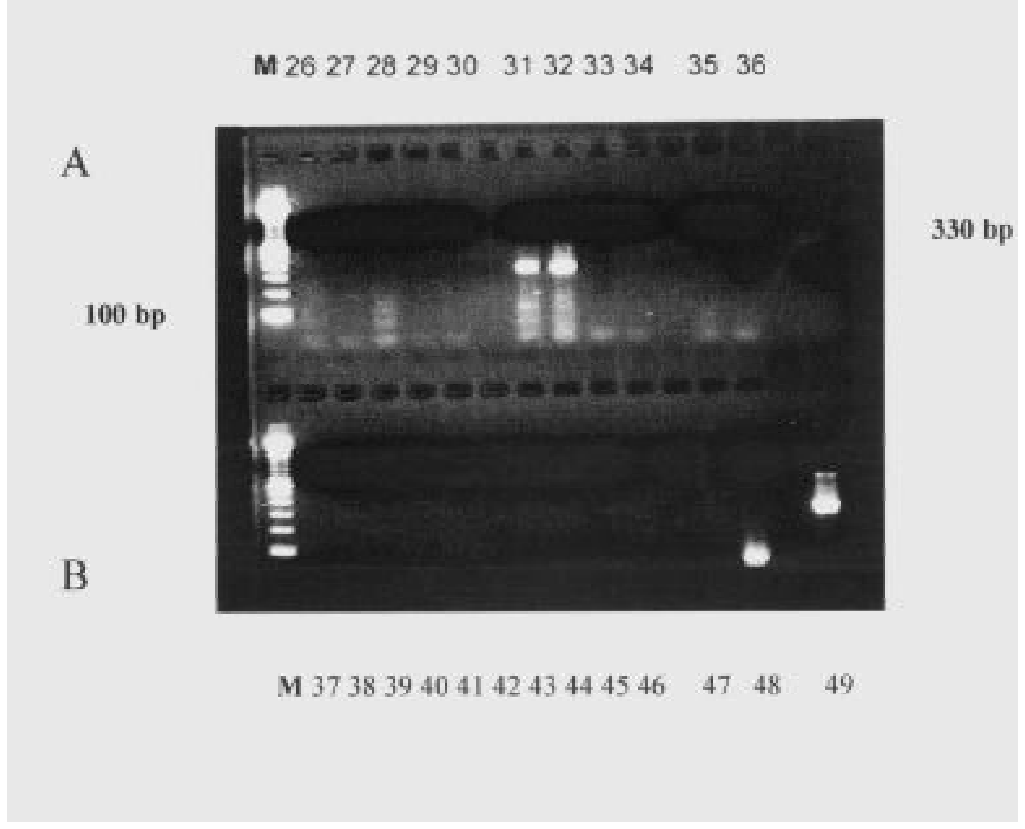

Figure 3 - $k$ DNA amplification: a: clone Cl-Col-C1 samples 26 to 30 and clone ClCol-C3: samples 31 to 34 and clone Cl-Col-C4: samples 35 and 36. $b$ : clone $\mathrm{Cl}-$ Col-C5: samples 37 to 46. Positive control (culture forms of T. cruzi): 49. Negative control (blood of normal mouse): 48. Negative control (ultra pure water without DNA samples): 47 . M-marker ladder: $100 \mathrm{bp}$. 


\section{$\begin{array}{llllllllllll}1 & 2 & 3 & 4 & 5 & 6 & 7 & 8 & 9 & 10 & 11 & 12\end{array}$}

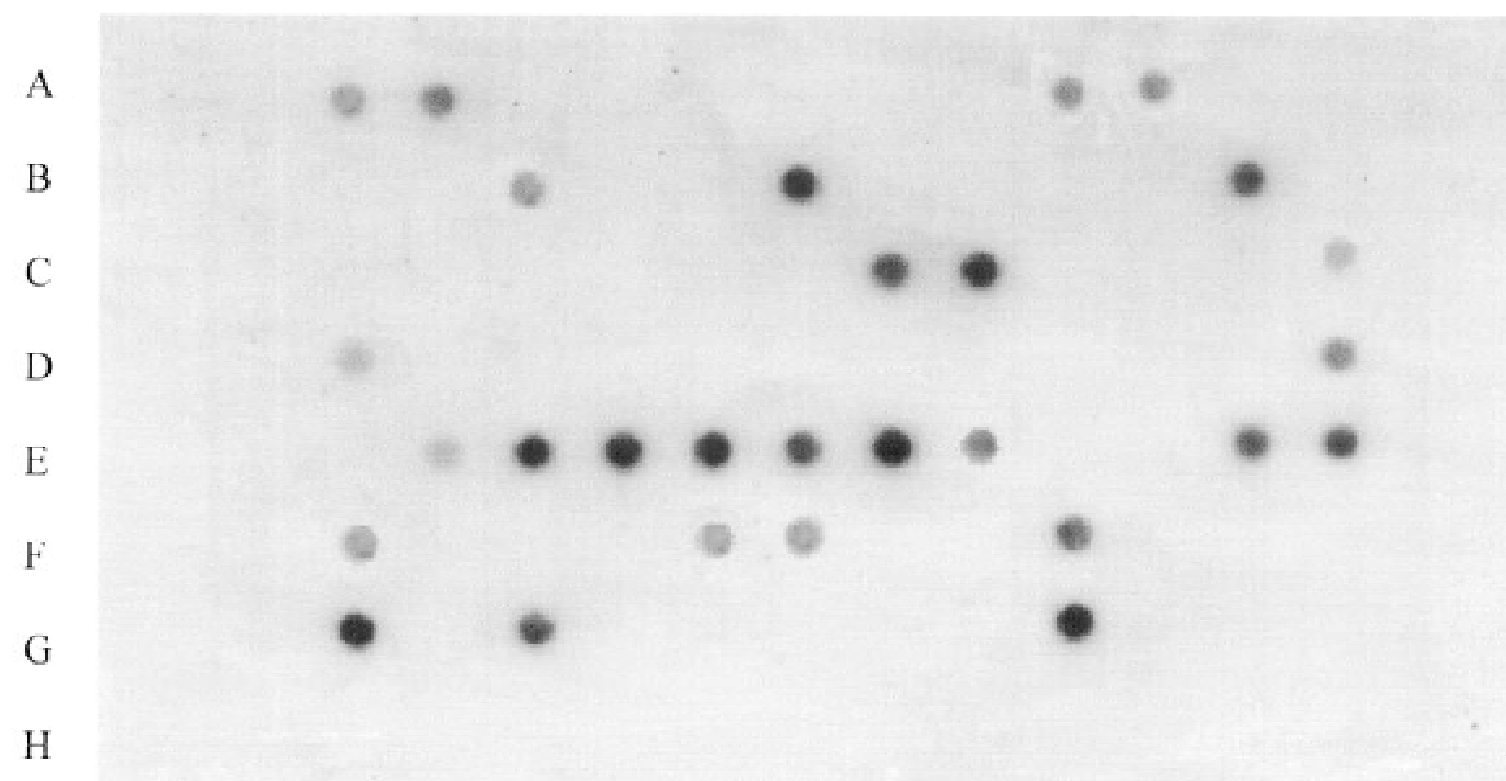

\begin{tabular}{|c|c|c|c|c|c|c|c|c|c|c|c|c|}
\hline & 1 & 2 & 3 & 4 & 5 & 6 & 7 & 8 & 9 & 10 & 11 & 12 \\
\hline A & Coll & ColP & UC & UC & UC & UC & ColN & ColN & $\mathrm{CIP}$ & Coll & $\operatorname{ColN}$ & ColN \\
\hline B & UC & $\mathrm{CIN}$ & $\mathrm{CIP}$ & CIN & CIN & CIP & CIN & CIN & $\mathrm{H}_{2} 0$ & $\mathrm{CN}$ & $\mathrm{PC}$ & $\mathrm{X}$ \\
\hline C & CIN & CIN & CIN & CIN & CIN & $\mathrm{x}$ & $\mathrm{ClP}^{\mathrm{P}}$ & $\mathrm{CIP}^{-}$ & $\mathrm{ClN}$ & $\mathrm{CIN}$ & $\mathrm{CIN}$ & $\mathrm{CIP}$ \\
\hline $\mathrm{D}$ & CIP & CIN & $\mathrm{CIN}$ & CIN & $\mathrm{CIN}$ & $\mathrm{CIN}$ & $\mathrm{CIN}$ & CIN & $\mathrm{CIN}$ & $\mathrm{H}_{2} 0$ & $\mathrm{NC}$ & $P C$ \\
\hline$E$ & $\mathrm{CIN}$ & $\mathrm{ClP}$ & $\mathrm{CIP}$ & CIP & $\mathrm{CIP}$ & $\mathrm{CIP}$ & $\mathrm{CIP}$ & $\mathrm{CIP}$ & $\mathrm{CIN}$ & CIN & $\mathrm{CIP}$ & $\mathrm{CIP}^{\mathrm{P}}$ \\
\hline$F$ & $\mathrm{CIP}$ & $\mathrm{X}$ & $\mathrm{CIN}$ & $\mathrm{CIN}$ & $\mathrm{CIP}$ & $\mathrm{CIP}$ & CIN & CIN & CIP & CIN & CIN & CIN \\
\hline $\mathrm{G}$ & $\mathrm{CIP}$ & $\mathrm{CIN}$ & $\mathrm{CIP}$ & $x$ & $\mathrm{H}_{2} 0$ & $\mathrm{x}$ & $\mathrm{CN}$ & $\mathrm{x}$ & $\mathrm{PC}$ & $\mathrm{x}$ & $X$ & $\mathrm{CIN}$ \\
\hline H & $\mathrm{x}$ & $x$ & $x$ & $x$ & $x$ & $x$ & $X$ & $X$ & $X$ & $\mathrm{X}$ & $x$ & $x$ \\
\hline
\end{tabular}

Iegends: CIP- clones PCR positive: CIN-clones PCR negative; ColP- Trealed parental sirain PCR positive; CollN: treated parental strain PCR regalive; UC- unireated sontrol; PC-positive control;NC- control negative( blos af normal mice): $\mathrm{H}_{2} \mathrm{O}$ - ultre purs water ; $\mathrm{X}$-without DNA sample;

Figure 4 -Hybridization by dot-blot technique with allele specific probe $P 67$ from the conserved region within the minirepeats of T. cruzi $k$ DNA minicircles. DNA samples from blood of infected mice, either with the parental T. cruzi strain or its clones; untreated or with benznidazole therapy, positive control (culture forms) and negative control. 
infected mice has a clear effect on parasitemia, which decreases to a sub-patent level. The seven clones of this strain although similar according to several biological parameters, revealed differences in the virulence ${ }^{14}$, clones $\mathrm{C} 1, \mathrm{C} 3, \mathrm{C} 4$ and $\mathrm{C} 6$ revealing the highest levels of parasitemia and mortality and clones $\mathrm{C} 2, \mathrm{C} 5$ and $\mathrm{C} 7$ the lowest virulence. This is reflected in the mortality rates in the treated animals. The parasitological tests revealed persistence of infection confirming the resistance to treatment of this strain and its clones. Results of cure tests indicate a low percentage (37\%) of concordance between the positivity of the combined serologic plus parasitological tests and PCR. These findings point to a difficulty in the use of PCR as a cure test in mice, considering the small volume of blood sample obtained from each mouse, resulting in the low sensitivity observed in the present study. A previous study by Campos et $\mathrm{al}^{17}$ investigated the sensitivity of PCR to reveal the presence of known aliquots of trypomastigotes added to the blood of normal mice in vitro. The findings indicated a high sensitivity of PCR to detect even one trypomastigote in the blood, but examination of several samples may be necessary. In the present study, only one sample of $500 \mu$ l was examined for each mouse. Furthermore, in the other parasitological tests (subinoculation of blood into newborn mice, haemoculture or xenodiagnosis), parasite multiplication occurs, increasing the possibilities of detecting low levels of parasitemia in the treated mice.

The predominance of resistant clones in T.cruzi strains is probably, responsible for the treatment failure, as seen in the endemic area of Central Brazil in patients infected with strains of the biodeme Type III, Z1 (T.cruzi I) contrasted to those infected with biodeme Type II , Z 2 ( $T$. cruzi II). Failures of clinical treatment of patients who carried T. cruzi strain of biodeme Type III, was believed to be related to the resistance of this strain type to anti-Chagas drugs. Concordance between the results obtained in patients and the experimental results obtained in mice infected with the same isolated strains was subsequently documented for $81.8 \%$ of the cases 6 . Clones obtained from the 21 SF strain (Type II) $^{15}$, have shown a medium susceptibility to treatment with benznidazole (data not published) similar to the behavior of the parental strain. This could suggest that treatment of patients with this type of strain can be successful and confirms the importance of the clonal structure of the parasite strain.

Predominance of resistant clones, as now demonstrated for the Colombian strain, may occur with other strains with the same characteristics, included in the biodeme Type $\mathrm{III}^{7}$. This fact may represent a serious challenge to Chagas' disease control in endemic areas, where a high incidence of chronically infected patients is detected by serological or PCR tests ${ }^{129}$.

\section{ACKNOWLEDGMENTS}

Thanks are due to Mr. Brendan L. Flannery (University of California, Berkeley, CA, USA), for language review.

\section{REFERENCES}

1. Andrade ALSS, Zicker F, Oliveira RM, Silva SA, Luquetti A, Travassos LR, Almeida IC, Andrade SS, Andrade JG. Randomised trílofeffcacyofloenznidazole inteatmentofearty Trypanosoma cruzi infection. The Lancet 348:1407-1413,1996

2. Andrade SG. Trypanosoma cruzi: clonal structure of parasite strains and the importance of principal clones. Memórias do Instituto Oswaldo Cruz 94:185-187, 1999.

3. Andrade SG, Figueira RM. Estudo experimental sobre a ação terapêutica da droga R07-1051 na infecção por diferentes cepas do T. cruzi. Revista do Instituto de Medicina Tropical de São Paulo 19: 335-341, 1977.

4. Andrade SG, Magalhães JB. Biodemes and Zymodemes of Trypanosoma cruzi: correlations with clinical data and experimental pathology. Revista da Sociedade Brasileira de Medicina Tropical 30: 27-35,1997.

5. Andrade SG, Magalhães JB, Pontes, AL Evaluation of chemotherapy with benznidazole and nifurtimox in mice infected with Trypanosoma cruzi strains of different types. Bulletin of the World Health Organization, 63: 721-726, 1985.

6. Andrade SG, Rassi A, Magalhães JB, Ferriolli Filho F, Luquetti AO. Specific chemotherapy of Chagas' disease: a comparison between the response in patients and experimental animals inoculated with the same strains. Transactions of the Royal Society of Tropical Medicine and Hygiene 86: 624-626, 1992.

7. Andrade V, Brodskyn C, Andrade SG. Correlation between isoenzyme patterns and biological behaviour of different strains of Trypanosoma cruzi. Transaction of the Royal Society of Tropical medicine and Hygiene 77: 796-799, 1983.

8. Anonymous. Recommendations from a Satellite Meeting. Memórias do Instituto Oswaldo Cruz 94 (supl 1): 429-432, 1999.

9. Ávila HA, Borges -Pereira J, Thiemann O, De Paiva E, Degrave, W, Morel CM , Simpson L. Detection of Trypanosoma cruzi in blood specimens of chronic chagasic patients by polymerase chain reaction amplification of kinetoplast minicircle DNA: comparison with serology and xenodiagnosis. Journal of Clinical Microbiology 31:2421-2426, 1993.

10. Ávila HA, Sigman DS, Cohen LM, Millikan RC, Simpson L. Polymerase chain reaction amplification of Trypanosoma cruzi kinetoplast minicircle DNA isolated from whole blood lysates: diagnosis of chronic Chagas' disease. Molecular Biochemistry Parasitology 48:211-222, 1991.

11. Britto C, Cardoso MA, Monteiro Vianni CM, Haslocher-Moreno A, Xavier, SS, Oelemann W, Santoro A, Pirmez C, Morel CM, Wincker P. Polymerase chain reaction detection of Trypanosoma cruzi in human blood samples as a tool for diagnosis and treatment evaluation. Parasitology 110: 241-247, 1995.

12. Britto C, Cardoso MA, Ravel C, Santoro AA, Pereira JB, Coura JR, Morel CM, Wincker P. Trypanosoma cruzi: parasite detection and strain discrimination in chronic chagasic patients from northeastern Brazil using PCR amplification of kinetoplast DNA and non radioactive hybridization. Experimental Parasitology 81: 462-471,1995. 
13. Britto C, Macedo V, Silveira C, Cardoso A, Marques P, Fernandes O. Potencial de aplicação da técnica de PCR na determinação de cura parasitológica em pacientes chagásicos crônicos submetidos a quimioterapia específica. Revista da Sociedade Brasileira de Medicina Tropical 32 (supl II): 77-78, 1999.

14. Camandaroba ELP, Campos RF, Magalhães JB, Andrade, S.G. Clonal structure of Trypanosoma cruzi Colombian strain (Biodeme Type (II): biological, isoenzymic and histopathological analysis of seven isolated clones. Revista da Sociedade Brasileira de Medicina Tropical 34: 151-157, 2001.

15. Campos RMF, Andrade SG. Characterization of subpopulations (clones and subclones) of the $21 \mathrm{SF}$ strain of Trypanosoma cruzi after long lasting maintenance in the laboratory. Memórias do Instituto Oswaldo Cruz 91:795-800, 1996.

16. Campos RMF, Gonçalves MS, Reis EAG, Reis MG, Andrade SG. Comparative analysis by polymerase chain reaction amplified minicircles of kinetoplast DNA of a stable strain of Trypanosoma cruzi from São Felipe, Bahia, its clones and subclones: possibility of predominance of a principal clone in this area. Memórias do Instituto Oswaldo cruz 94: 23-29, 1999.

17. Campos RF, Magalhães JB, Reis EAG, Reis MG, Andrade SG. Sensitivity of the polymerase chain reaction for detection of known aliquots of Trypanosoma cruzi in the blood of mice: an in vitro study. Revista da Sociedade Brasileira de Medicina Tropical 35: 487-490, 2002

18. Dvorak JÁ. Single Cell Isolates of Trypanosoma cruzi: How and Why? Revista da Sociedade Brasileira de Medicina Tropical 18 (supl): 29-38, 1985.

19. Fragata Filho AA, Luquetti AO, Prata A, Rassi A, Gontijo ED, Ferreira HO, Cançado JR, Coura JR, Andrade SG, Macedo V, Amato Neto A, Oliveira Jr W, Brener Z. Ethiological treatment for Chagas' disease. Parasitology Today 13:127-128, 1997.

20. Federici EE, Abelmann WB, Neva FA. Chronic and progressive myocarditis and myositis in $\mathrm{C} 3 \mathrm{H}$ mice infected with Trypanosoma cruzi. The American Journal of Tropical Medicine and Hygiene 13: $272-280,1964$
21. Filardi LS, Brener Z. Nitroimidazole-thiadiazole derivative with curative action in experimental Trypanosoma cruzi infections. Annals of Tropical Medicine and Parasitology 176: 293-287,1982.

22. Marretto JPM, Andrade SG. Biochemical behavior of Trypanosoma cruzi strains isolated from mice submitted to specific chemotherapy. Revista da Sociedade Brasileira de Medicina Tropical 27: 209-215, 1994.

23. Miles MA, Lanham SM, Souza, AA, Póvoa M. Further enzymic characters of Trypanosoma cruzi and their evaluation for strain identification. Transactions of the Royal Society of Tropical Medicine and Hygiene 74: 221-237, 1980.

24. Murta SMF, Romanha AJ. In vivo selection of a population of Trypanosoma cruzi and clones resistant to benznidazole. Parasitology 116: 165-171, 1998.

25. Revollo S, Oury B, Laurent J-P, Barnabé C, Quesney V, Carrière V, Nöel S, Tibayrenc M. Trypanosoma cruzi: impact of clonal evolution of the parasite on its biological and medical properties. Experimental Parasitology 89: 30-39, 1998.

26. Tibayrenc M, Ward P, Moya A, Ayala FJ. Natural population of Trypanosoma cruzi, the agent of Chagas' disease, have a complex multiclonal structure. Proceedings of the National Academy of Science of Unites States of America 83:115-119, 1986.

27. Tibayrenc M, Brenière SF. Trypanosoma cruzi: major clones rather than zymodemes. Memórias do Instituto Oswaldo Cruz 83: 249-255, 1988.

28. Warren LG. Metabolism of Schizotrypanum cruzi Chagas. Effect of culture age and substrate concentration on respiratory rate. Journal of Parasitology 46:529-539, 1960.

29. Wincker P, Britto C, Pereira JB, Cardoso A, Oelemann W, Morel $\mathrm{CM}$. Use of a simplified polymerase chain reaction procedure to detect Trypanosoma cruzi in blood samples from chronic chagasic patients in a rural area. The American Journal of Tropical Medicine Hygiene 51:771-777, 1994.

30. World Health Organization. Control of Chagas' disease. Report of a WHO Expert Committee. WHO Technical Report Series, Geneva 81-95, 1991. 